\title{
Investigating the Role of Job Engagement and Job Self-Efficacy With Job-Family Conflict in Female Nurses of Tehran
}

\author{
Helia Rahimi $^{1}$, Abdolrahim Kasaee ${ }^{2}$, Esmail Asadpour ${ }^{3 *}$ \\ 1. MA, Family Counseling, Kharazmi University, Tehran, Iran \\ 2. Academic Member, Department of counseling, Faculty of Psychology and Educational Sciences, Kharazmi \\ University, Tehran, Iran \\ 3. Academic Member, Department of Counseling, Faculty of Psychology and Educational Sciences, Kharazmi \\ University, Tehran, Iran
}

\begin{tabular}{l} 
Article Info \\
\hline Received: 2018/01/05; \\
Accepted: 2018/04/22; \\
Published Online: $2018 / 08 / 04$ \\
DOI: \\
$\underline{\text { 10.30699/sjhnmf.26.6.366 }}$ \\
Original Article
\end{tabular}

Use your device to scan and read the article online

Corresponding Information:
ABSTRACT

Introduction: A lot of nurses face the challenge of balancing their job and family roles.The purpose of this study was to investigate the role of job engagement and job self-efficacy in predicting job-family conflict among female nurses.

Methods: In this descriptive-correlational study, the statistical population was all 12000 female nurses of Tehran state hospitals in the second three months of 2016. Out of this population, 381 subjects were selected via cluster sampling method, and were evaluated via family-job and self-efficacy questionnaires. For statistical analysis of data the SPSS22 and the descriptive and inferential statistics methods such as Pearson correlation coefficient and multiple stepwise regression were used. The significance level in this study was 0.05 .

Results: The results showed a significant negative correlation between the overall job engagement score and its components $(P \leq 0.01, \mathrm{~F}=28 / 127)$. In addition, there is a negative significant correlation between components of job self-efficacy and overall score of self-efficacy with job-family conflict and family-job conflict ( $P \leq$ $0.05, \mathrm{~F}=126 / 93)$.

Conclusion: Job engagement and job self-efficacy reduce job-family conflict. Therefore the obtained results from this research can be used in nurses' curriculum designing to reduce job-family conflict.

Keywords: Job engagement, Job self- efficacy, Job-Family conflict, Nurses

Esmail Asadpour, Academic Member, Department of Counseling, Faculty of Psychology and Educational Sciences, Kharazmi University, Tehran, Iran. E-Mail:Dr.iasadpour@yahoo.com

Copyright $\odot$ 2019, Sci J Hamadan Nurs Midwifery Fac. This is an open-access article distributed under the terms of the Creative Commons Attribution-noncommercial 4.0 International License which permits copy and redistribute the material just in noncommercial usages, provided the original work is properly cited.

\section{How to Cite This Article:}

Rahimi H, Kasaee A, Asadpour E. Investigating the Role of Job Engagement and Job Self-Efficacy With Job-Family Conflict in Female Nurses of Tehran. Sci J Hamadan Nurs Midwifery Fac. 2019; 26 (6) :366-376 


$$
\text { مقاله يثروهشى }
$$

بررسى ارتباط ميان اشتياق و خودكار آمدى شغلى با تعارض شغل - خانواده در يرستاران زن شهر تهران

هليا رحيمى'، عبدالرحيم كسائى ‘، اسماعيل اسديور بّ"

ا. ا. كارشناس ارشد مشاورة خانواده، دانشكدة روانشناسى و علوم تربيتى، دانشكاه خوارزمى، تهران، ايران

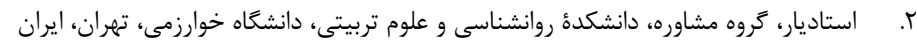

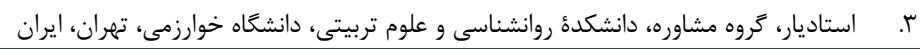

\begin{tabular}{|c|c|}
\hline جكيده & اطلاعات مقاله \\
\hline 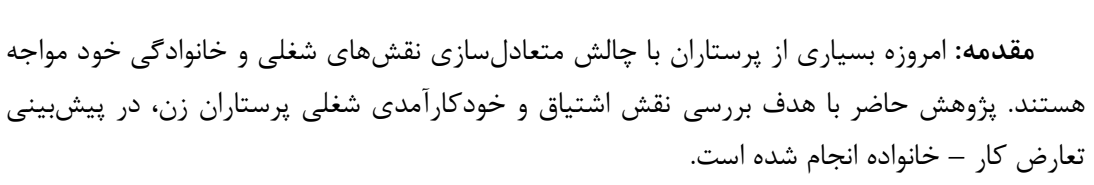 & 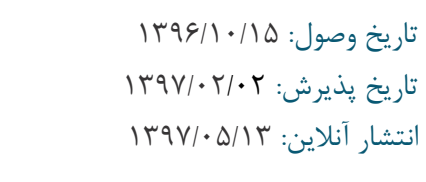 \\
\hline 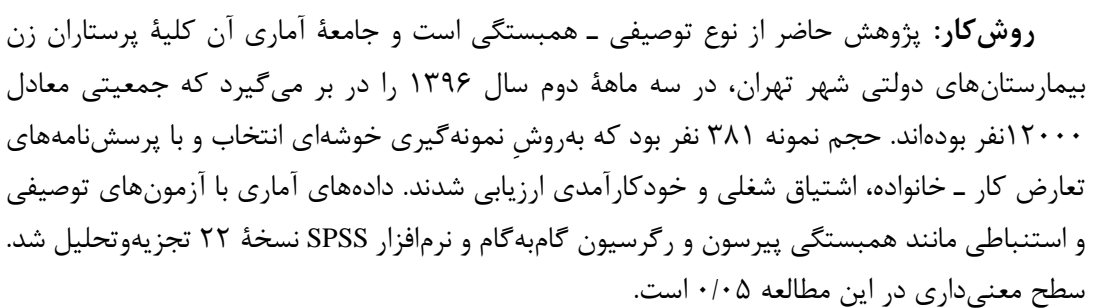 & 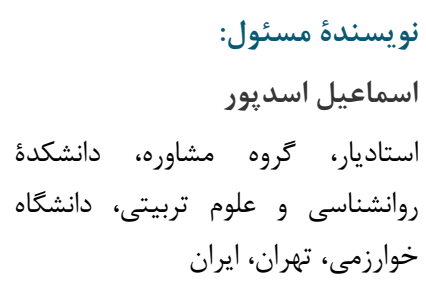 \\
\hline 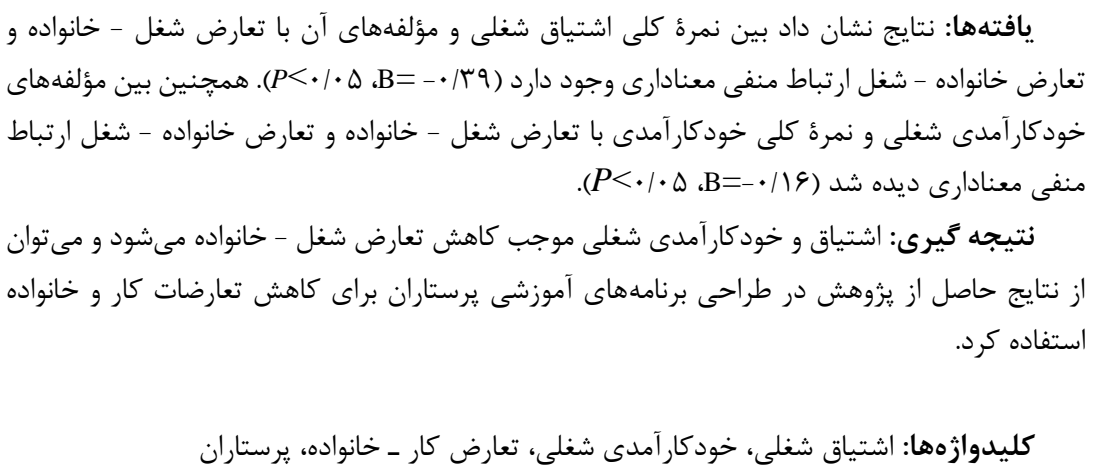 & 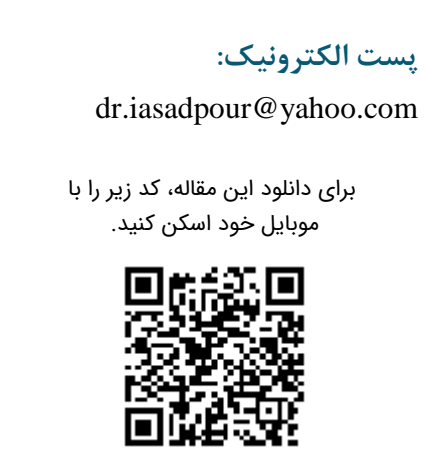 \\
\hline
\end{tabular}

مقلمهه

موجب از دستدادن مهارتها، تخصص و منابع نيز مىشود

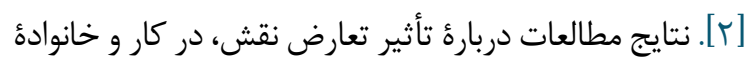

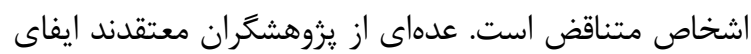

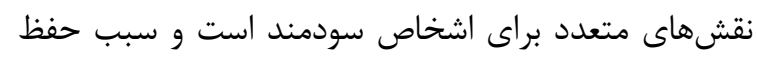

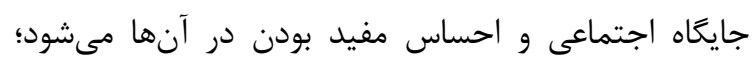

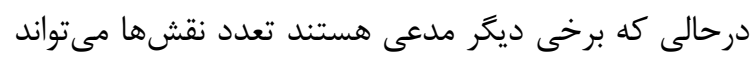
سلامت اشخاص را به خطر بيندازد [ب]. تعارض كار- خانواده از مسائل اساسى مدنظر فعالان

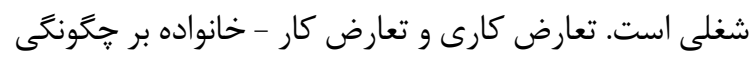
زندگى كارى، و تعارض خانوادىى و تعارض خانواده - كار بر

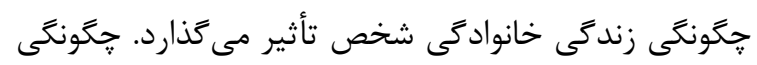

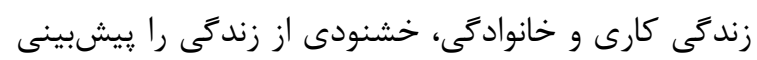

بسيارى از يرستاران امروزه با جالش متعادلسازى نقشهاى شغلى و خانوادكى خود مواجه هستند. هنوز دقيقاً

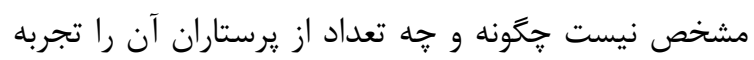

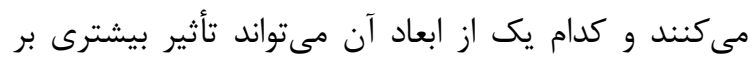
عملكرد آنها داشته باشد، اما نتايج مطالعات شيوع و تكرار

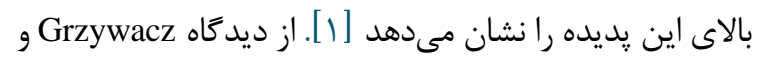

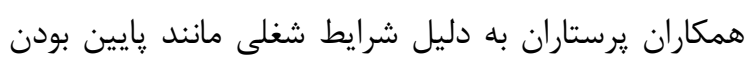
حمايت سازمانى، تعداد زياد شيفتهاى كارى، دشوارى كارى كار،

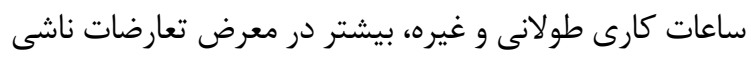
از كار و خانواده قرار دارند و هر ساله تعداد زيادى از يرستاران

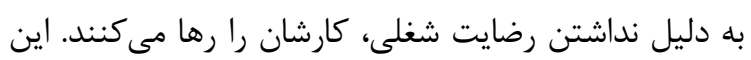
امر علاوه بر اتلاف هزينههاى صرفشده براى آموزش آنها، رئن 
افرادى كه به توانايىهاى خود اعتقاد ندارند، در موقعيتهاى بحرانى دجار ناميدى و درماندگى مىشوند و واحتى احتمال اينكه

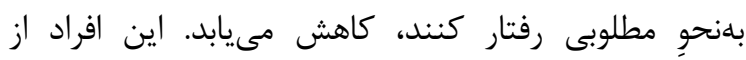

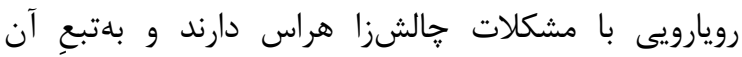

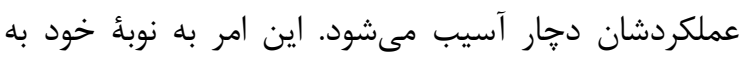

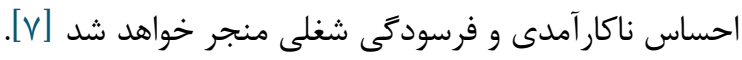

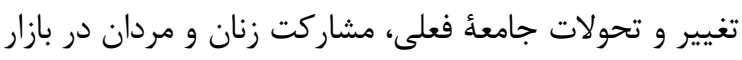

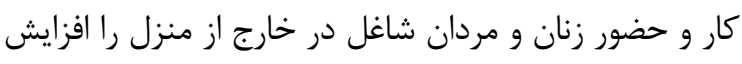

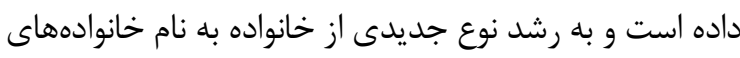

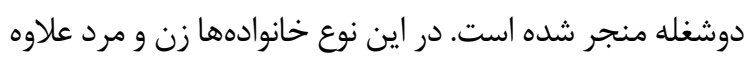
بر نقش سنتى همسرى و والدينى، نقش شغلى نيز دارند و اين ندان

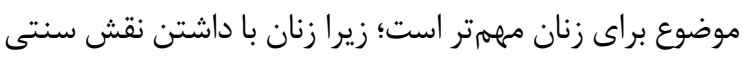

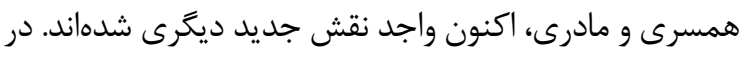

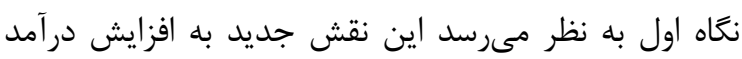

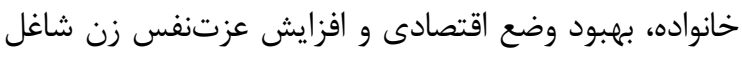

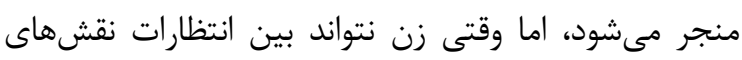

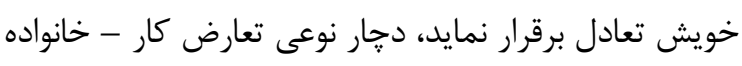

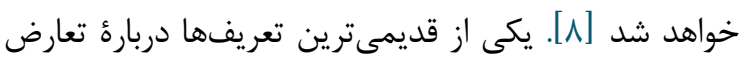

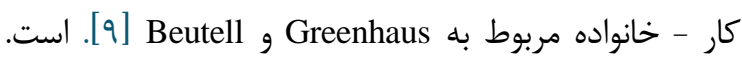
براساس اين تعريف، تعارض كار - خانواده نوعى اصطكاك نقشها است كه در آن فشارهاى ناشى از حيطؤ كار و خانواده

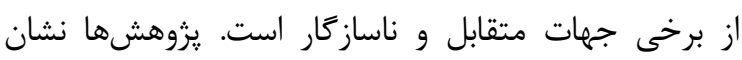

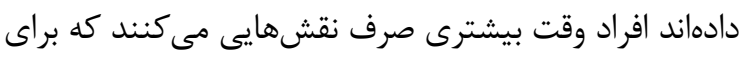

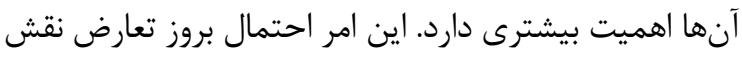

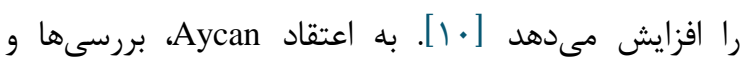

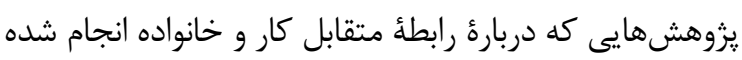

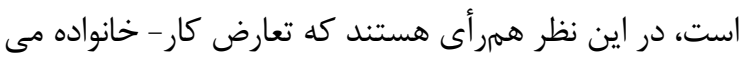

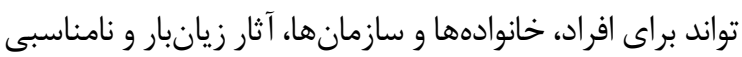

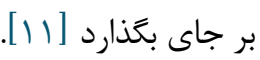

يزوهش Lim رابطؤ مستقيم و معنادار خودكارآمدى با بال

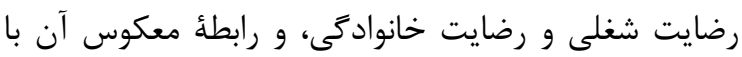

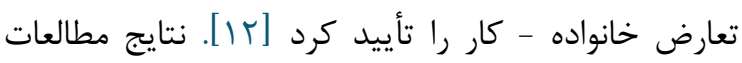
Rubio

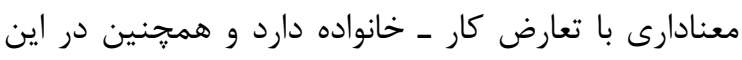

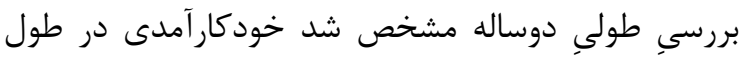

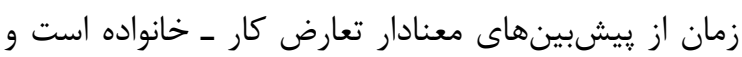
باعث كاهش اين نوع تعارض مىشود [بر إ].
مى كنند. تعارض كار ـ خانواده نوعى تعارض بين نقشى است

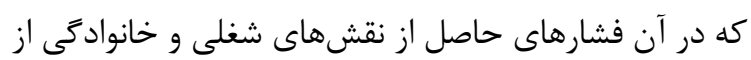

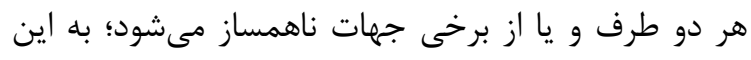
معنى كه مشاركت در نقش كارى و يا خانوادكى رانى را دشوار

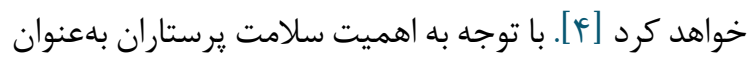
عضو اصلى سيستم سلامت كشور كه وظيفه حفظ سلامت

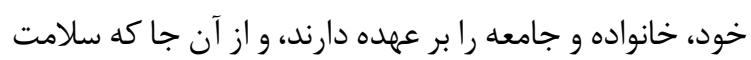

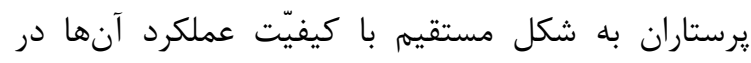

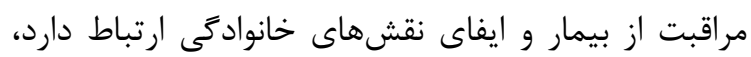

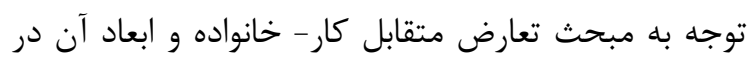

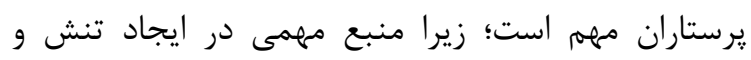

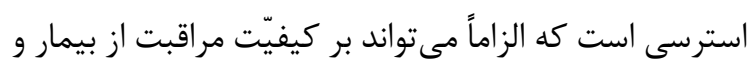

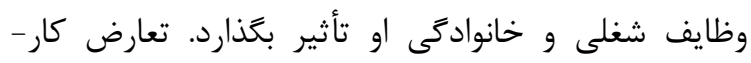

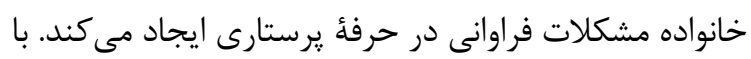

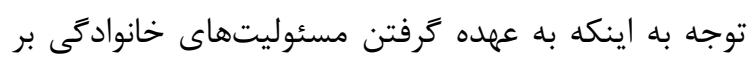

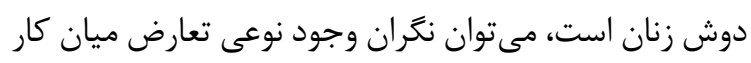

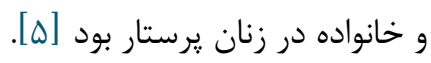

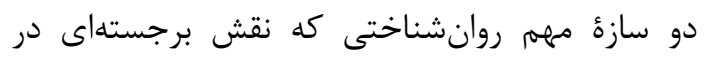

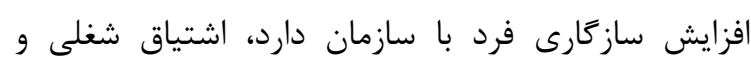

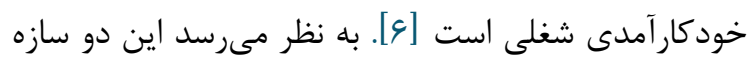

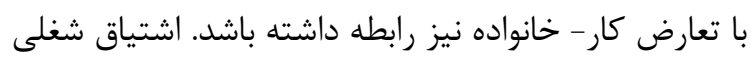

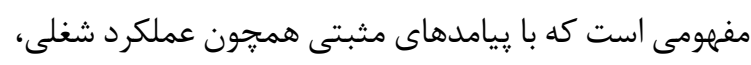

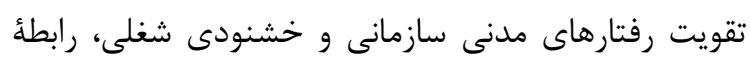
مثبت و با قصد ترك شغل رابطهُ منفى معنى دارى دارى دارد.

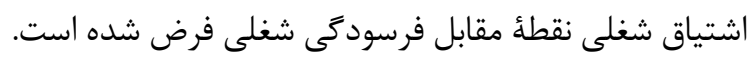

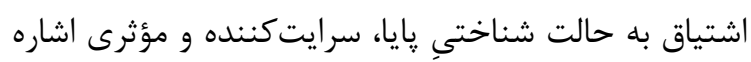

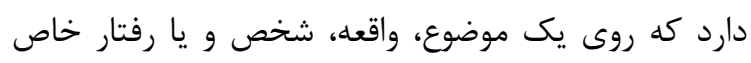

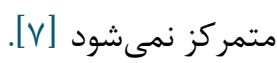

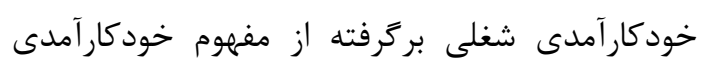

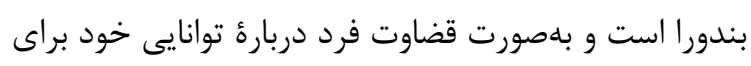

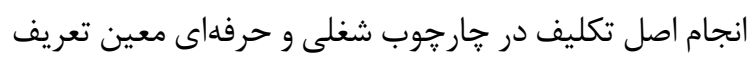

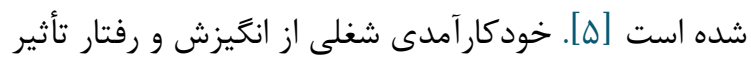

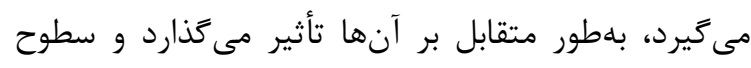

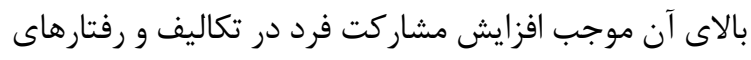

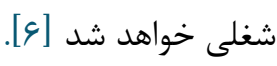
نظريهٔ خودكار آمدى بر اين فرض مبت أنسى است كه باور افراد

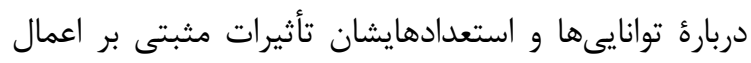
آنها دارد و مههمترين عنصر تعيينكننده در رفتار است. 
يك (كاملا مخالف) تا كزينهُ ينج (كاملا موافق)، براساس مقياس ليكرتى مرتب شده است. اين مقياس ابعاد 9 كانأه

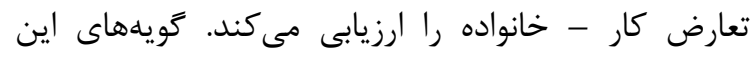

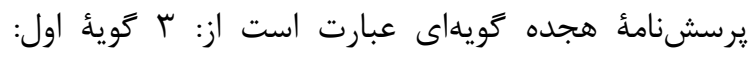

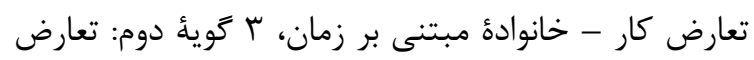

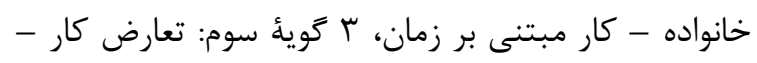

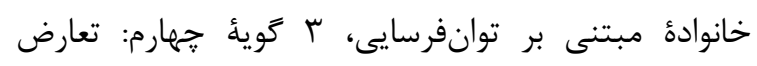

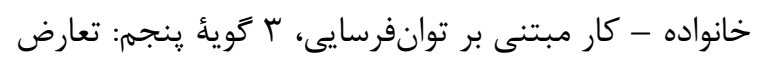

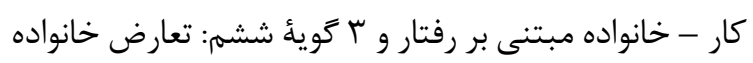

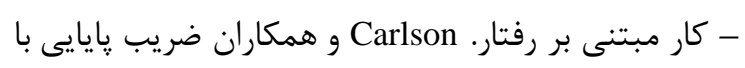

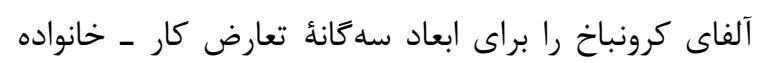

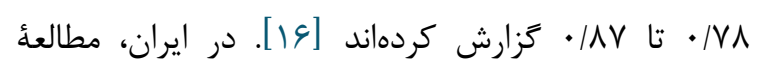
Watai

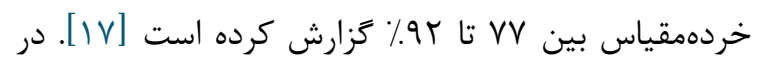

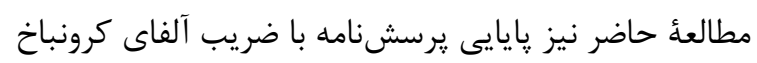
|AF

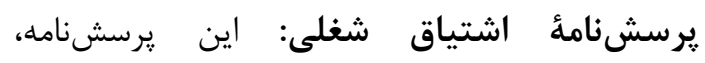
يرسشنامة خودارزيابى موسوم به مقياس اشتياق شغلى إنى

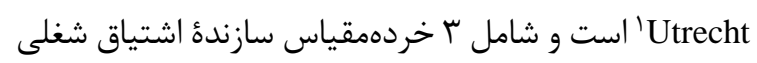

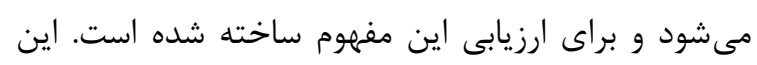

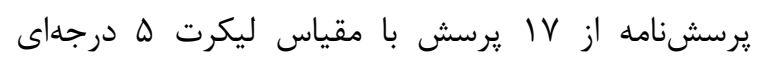

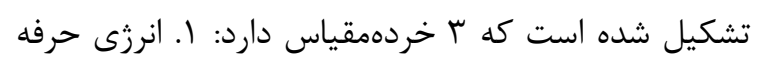

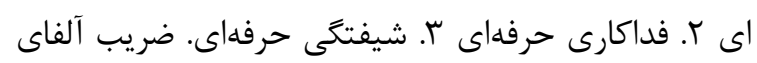

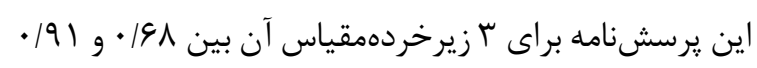
متغير است. همجنين Mauno و همكاران، آلفاى كرونباخ

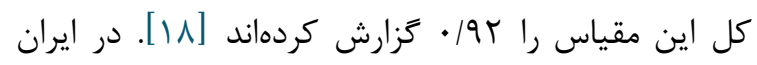
Hayati

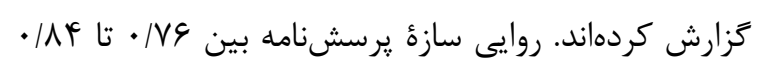

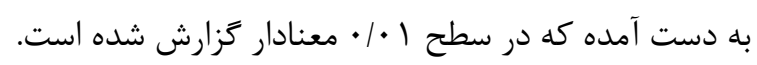

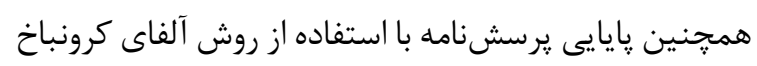

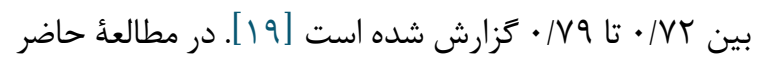
آلفاى كرونباخ براى كل ابزار AVV • • بوده است.

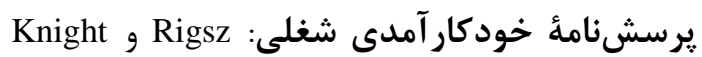

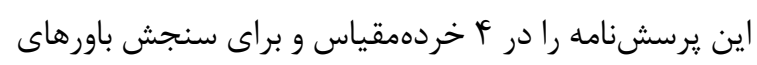

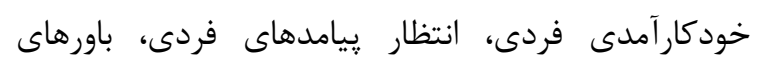

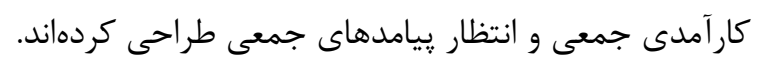

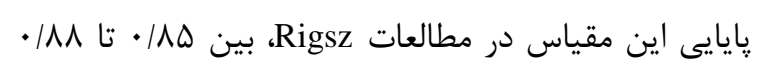

يافتههاى Peng و همكاران نشان داد خودكارآمدى و

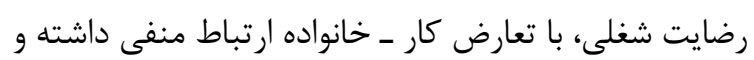

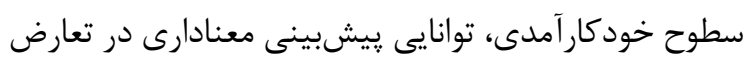

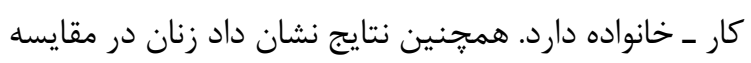

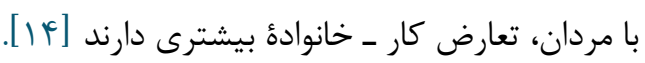

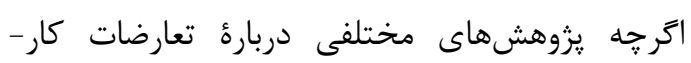

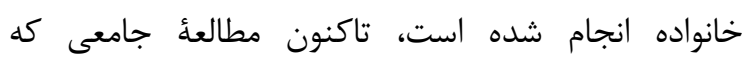

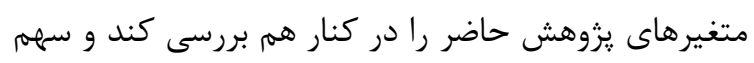

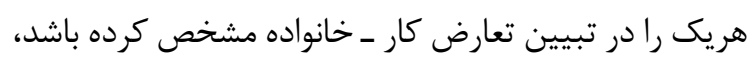

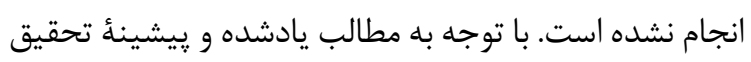

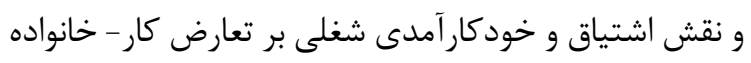

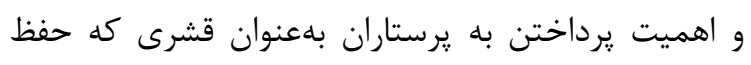

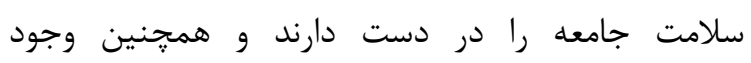

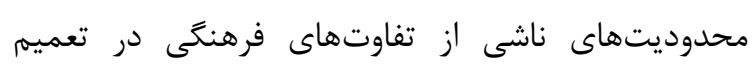

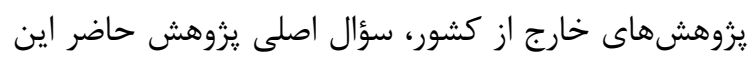

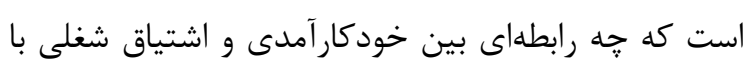

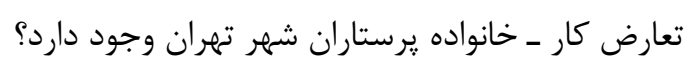

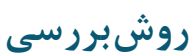

يزوهش حاضر با توجه به ماهيت متغيرهاى بررسى آنده،

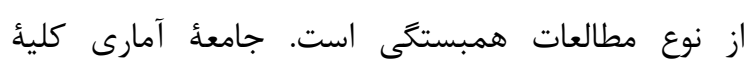

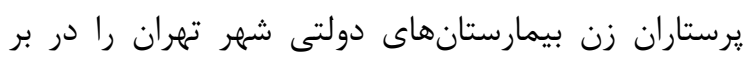

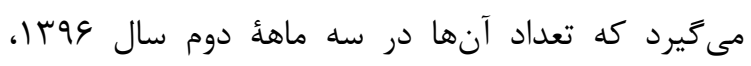

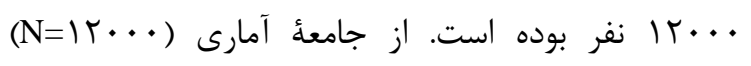

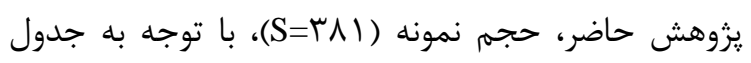

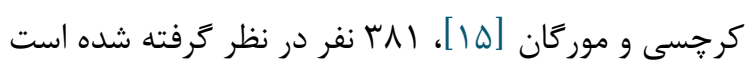

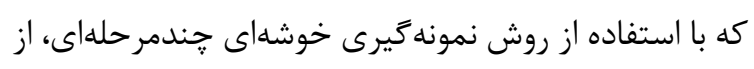

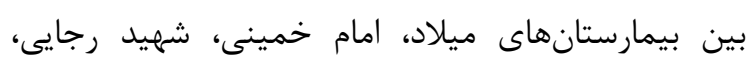

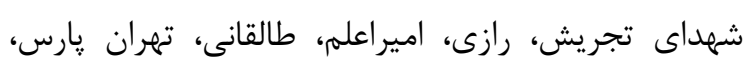

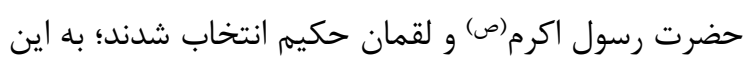

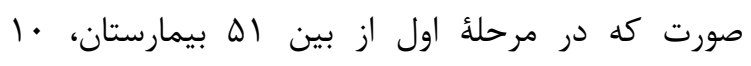

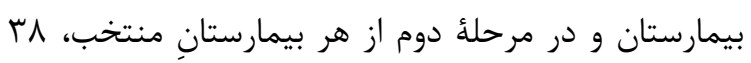

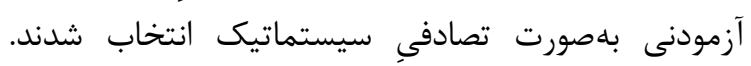

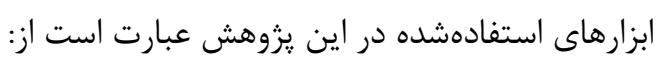

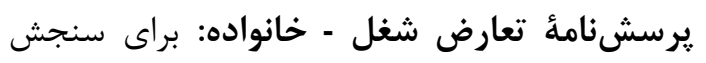

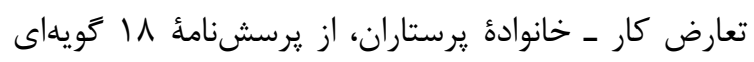

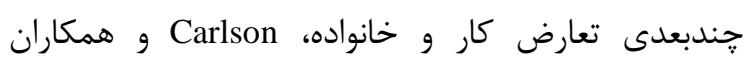
استفاده شده است. در اين مقياس، دامنهُ پِاسخها از خزينه

${ }^{1}$ Utrecht Work Engagement Scale

دورة צY شمارة 9 - بهمن و اسفند VY IT 
حضورى منطق يزوهش براى اين افراد توضيح داده شد و

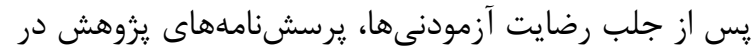

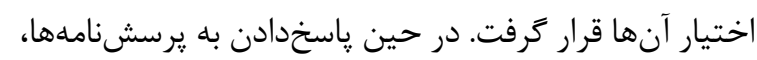

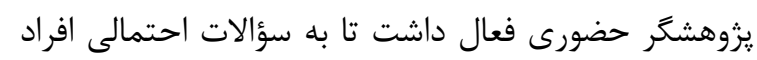

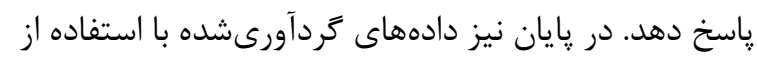

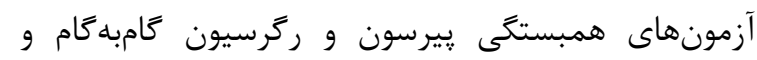

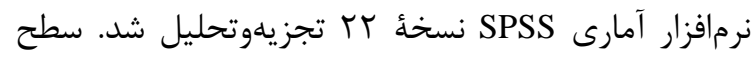
معنى دارى در اين مطالعه هـ • • بوده است.

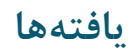

در يزوهش حاضر ميانكين سنى شركتكنندكان

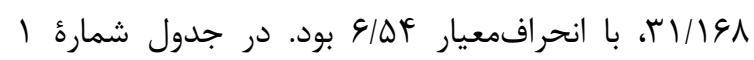
فراوانى و درصد وضعيت تأهل آزمودنىها ارائه شده است.
كزارش شده است. يايايى به روش آلفاى كرونباخ براى

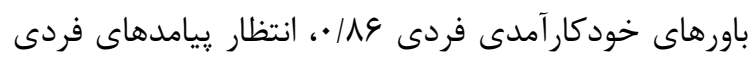

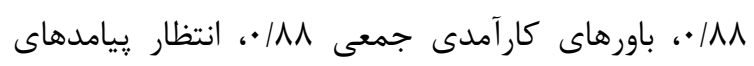

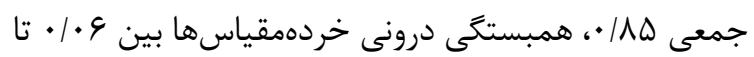

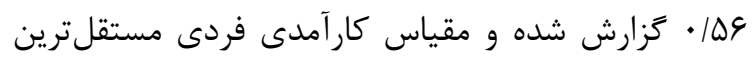

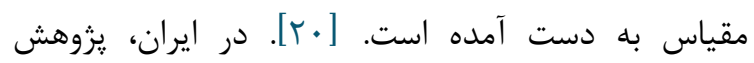
Maderi Mashian

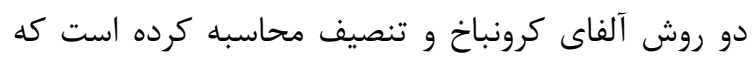

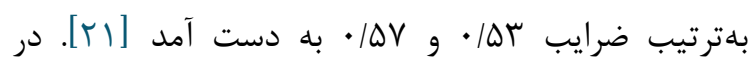

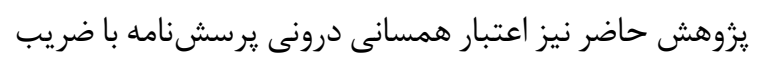

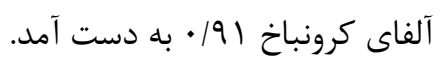

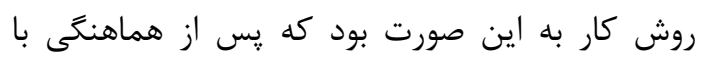

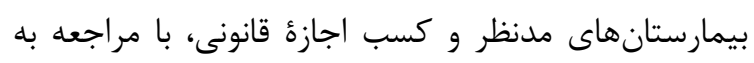

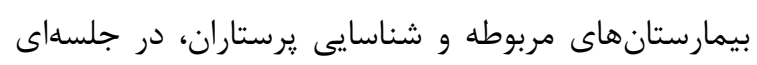

جدول شماره ا. فراوانى و درصد وضعيت تأهل و نوبت كارى آزمودنىها

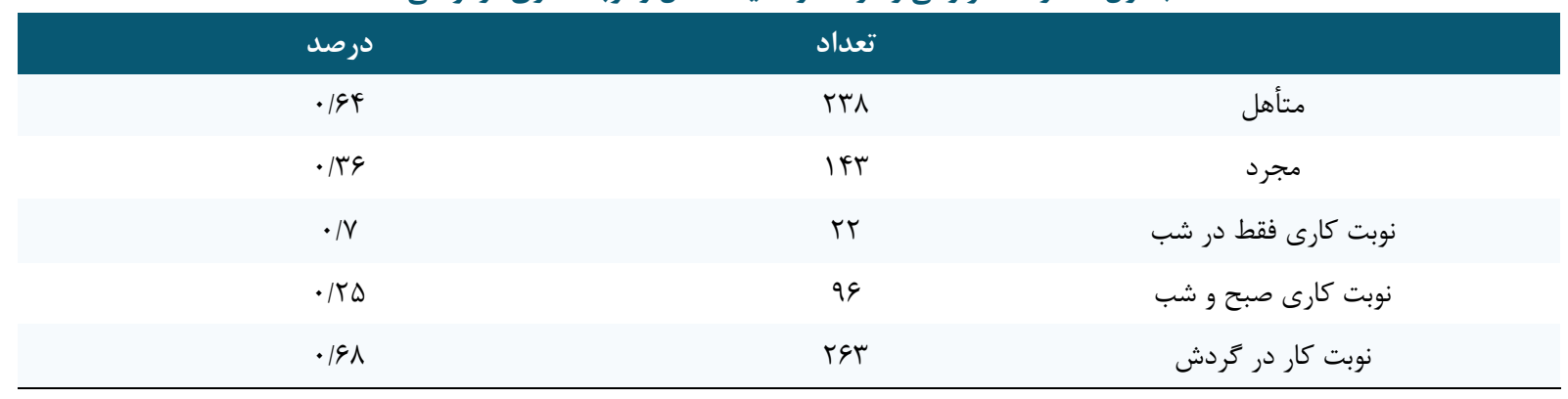

\begin{tabular}{|c|c|c|c|}
\hline انحر اف استاندارد & ميانگَين & 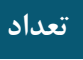 & متغير \\
\hline N/TY & $I V / T \Lambda$ & rNI & تعارض شغل ـ خانواده \\
\hline r/d & $11 / \Delta \Delta$ & r人l & تعارض خانواده ـ شغل \\
\hline $9 / \Delta \Lambda$ & IF/VT & rیl & انرزى حرفهاى \\
\hline$r / \cdot r$ & $\mid r / G K$ & rیl & فداكارى حرفهاى \\
\hline$\Delta / V \nabla$ & $14 / 9$ & rیl & شيفتخى حرفهاى \\
\hline$\Lambda / \Delta$ & $|f| / 1 \mid$ & rیl & نمرء كلى اشتياق شغلى \\
\hline $9 / 4 \wedge$ & T\&/19 & rیl & باورهاى خود كار آمدى فردى \\
\hline$V / 4 G$ & rr/Vq & Ґیl & انتظار رِيامدهاى فردى \\
\hline N/9V & IN/AT & rیl & باورهاى كارآمدى جمعى \\
\hline$g|f|$ & $1 \Delta / \mu$. & Ґیl & انتظار يِيامدهاى جمعى \\
\hline$T Y / Q F$ & $\Lambda F / 1 r$ & rیl & نمرءٔ كل خود كار آمدى شغلى \\
\hline
\end{tabular}

بررسى يِيشبينى تعارض كار- خانواده در يرستاران و از

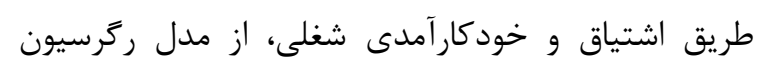

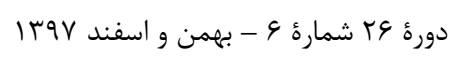

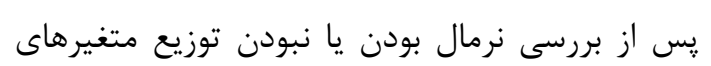

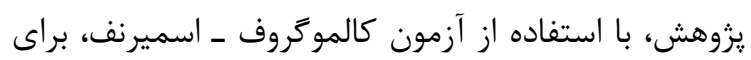
مجله علمى دانشكدة يرستارى و مامايى همدان 
هليا رحيمى و همكاران IVT

هليا رحيمى و همكاران ال

اين توزيع. با توجه به مقدار معنىدارى و ردنشدن فرضيئ

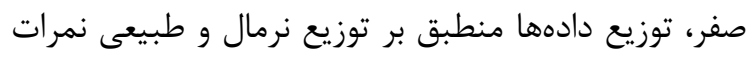

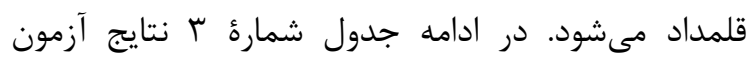

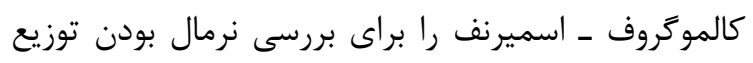

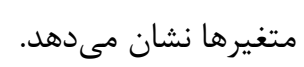

جندمتغيرى كامبهَام استفاده شد. از طريق اين آزمون

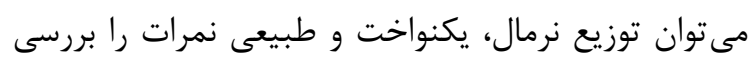

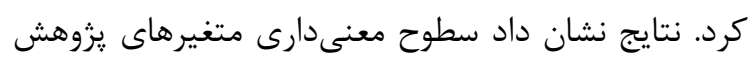

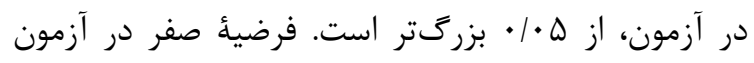

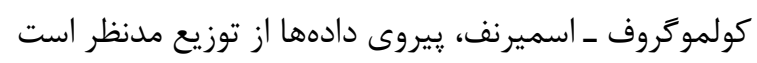

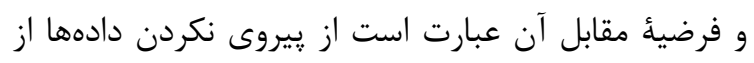

جدول شمارهُ r. نتايج آزمون كالموكروف ـ اسميرنف، براى بررسى نرمال بودن توزيع متغيرها
سطح معنى دارى
كالموَروف ـ اسميرنف
متغير

\begin{tabular}{|c|c|c|}
\hline •/TIT & $1 / \Delta r$ & تعارض شغل ـ خانواده \\
\hline.$|9| 0$ & $\cdot / V \cdot r$ & انرزى حرفهاى \\
\hline . I I & $1 / \cdot 14$ & فداكارى حرفهاى \\
\hline - & $|/ 4|$ & شيفتتى حرفهاى \\
\hline - IAVT & $.199 \mathrm{~V}$ & نمرء كلى اشتياق شغلى \\
\hline$\cdot 10 \cdot 9$ & $\cdot / 941$ & باورهاى خودكارآ مدى فردى \\
\hline . / frqq & . 1 1А9 & انتظار پيامدهاى فردى \\
\hline$\cdot|\Delta| T$ & $\cdot|A| \&$ & باورهاى كارآمدى جمعى \\
\hline. $\mid G M V$ & $\cdot / Q F V$ & انتظار پِيامدهاى جمعى \\
\hline$\cdot /$ rV & $1 / T Y Q$ & أرامدى شغلى \\
\hline
\end{tabular}

خانواده - شغل ارتباط منفى معنادارى وجود دارد و بين بررسى فرضيءٔ اول يزوهش: بين اشتياق و و

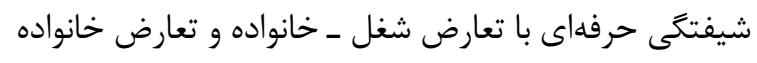
خودكار آمدى شغلى با تعارض شغل - خانواده يرستاران رابطه

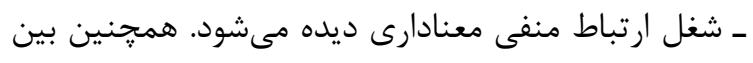
وجود دارد.

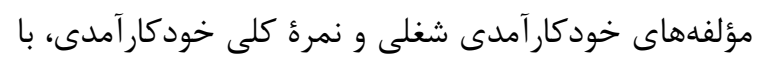
همان گونه كه در جدول شمارؤ f مشاهده مى مَود، بين

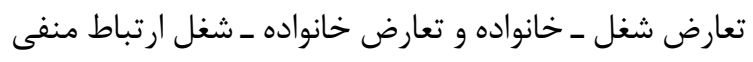

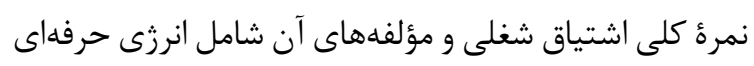

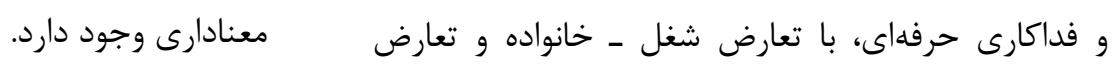

جدول شمارة F. ماتريس همبستكى متغير هاى يزوهش 


\begin{tabular}{|c|c|c|c|c|c|c|c|c|c|c|c|c|}
\hline \multirow[t]{11}{*}{11} & 1. & & 9 & $\Lambda$ & $\checkmark$ & 9 & $\Delta$ & p & $r$ & $r$ & 1 & متغير \\
\hline & & & & & & & & & & & 1 & تعارض شغل ـ خانواده \\
\hline & & & & & & & & & & 1 & $\cdot / 4 V \Lambda$ & تعارض خانواده ـ شغل \\
\hline & & & & & & & & & 1 & $-\cdot / N I V$ & $-\cdot \mid G M T$ & انرزى حرفهاى \\
\hline & & & & & & & & 1 & 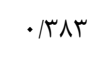 & $-\cdot / 1 \Delta \Delta$ & $-\cdot / 4 F \Lambda$ & فداكارى حرفهاى \\
\hline & & & & & & & 1 &.$- / K F r$ & $-\cdot / \& A V$ &.$/ 19 V$ & . $/ \Delta T S$ & شيفتگى حرفهاى \\
\hline & & & & & & 1 & .1 .94 &.$/ 219$ & .1994 & - & $-\cdot /$ FTr & نمرءٔ كلى اشتياق شغلى \\
\hline & & & & & 1 & $\cdot / r \cdot 9$ & $-\cdot / F F$. & $\cdot / K F \wedge$ & $\cdot \mid 491$ & $-\cdot / r 91$ & $-\cdot \mid \Delta F \Delta$ & فاورهاى خودكارآ مدى \\
\hline & & & & 1 & $\cdot / \cdot V r$ & $\cdot 19 \Lambda$ & $-\cdot / l V V$ & .1 .99 & - & $-\cdot 11 T 9$ & $-\cdot 11 \cdot 4$ & انتظار קيامدهاى فردى \\
\hline & & & 1 & $\cdot / r \cdot r$ & $\cdot / 4 \notin 4$ & $\cdot /$ r & $-\cdot / \Delta Q T$ & $\cdot /$ • ८ & $\cdot|\Delta| F$ & $-\cdot / r \Delta \Delta$ & $-\cdot|09|$ & باورهاى كار آمدى جمعى \\
\hline & 1 & $\cdot 10 r 9$ & & $\cdot 1119$ & $\cdot / \Delta T V$ & 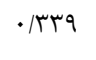 & $-\cdot|\Delta T|$ & $\cdot / r \wedge$ & $\cdot \mid \Delta \& \Lambda$ & $-\cdot /$ rیr &.$- / 494$ & انتظار رِيامدهاى جمعى \\
\hline 1 & . IVAr & $\cdot / \Lambda \cdot V$ & & . / $\Delta r$. & $\cdot|V \vee|$ & . /rar & $-\bullet / \Delta 9$ & $\cdot / F \mid \Lambda$ & - /DIr & $-\bullet / M T F$ & $-.194 \Delta$ & نمره كلى خودكار آمدى \\
\hline
\end{tabular}

ضريب تبيين به • له/· رسيد. ضرايب بتا برعكس افزايش

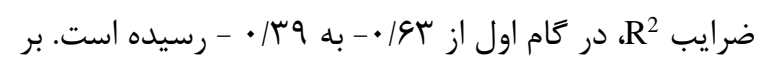
اين اساس مىتوان קنين استنباط كرد كه بر مبناى ضرايب

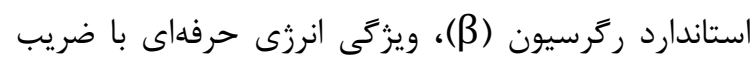

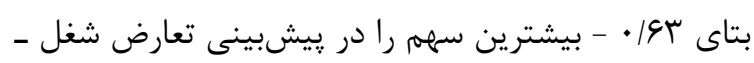

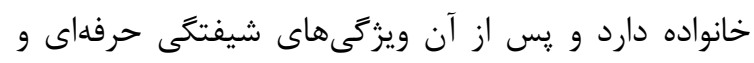
نمرء كلى اشتياق شغلى قرار دارند.
بررسى فرضيةٌ دوم يزوهش: بين اشتياق شغلى و تعارض - شغل خانواده يرستاران رابطه وجود دارد.

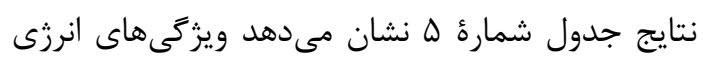

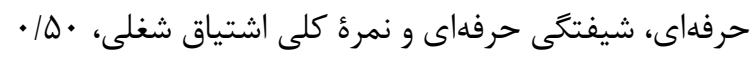

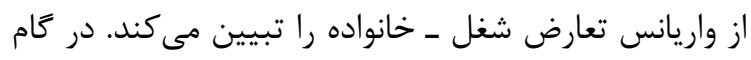

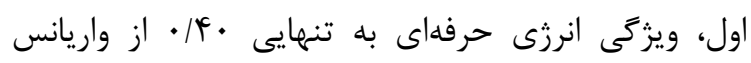

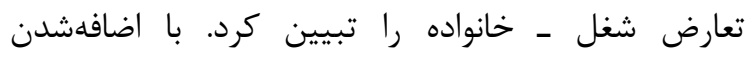
ويززگ هاى شيفتگى حرفهاى و نمره كلى اشتياق شغلى اين

جدول شماره ه. نتايج تحليل ركرسيون كامبهَّام براى يِيشبينى تعارض شغل ـ خانواده براساس اشتياق شغلى 
هليا رحيمى و همكاران سVr

\begin{tabular}{|c|c|c|c|c|c|c|c|c|c|}
\hline معنىدارى & $\mathbf{T}$ & Beta & $\begin{array}{c}\boldsymbol{\beta} \\
\text { استاندارد }\end{array}$ & ضريب & df & $\begin{array}{c}\mathbf{R}^{2} \\
\text { تعديلشده }\end{array}$ & $\mathbf{R}^{2}$ & $\mathbf{R}$ & متغير هاى بيشبين \\
\hline$\cdot 1 \cdots$ & $-\mid \Delta / \Lambda \Lambda$ & - & $-\cdot / V 9$ & TQT/QG & $(1-r \wedge \cdot)$ & . & $\cdot / 4$. & . & انرزى حرفهاى \\
\hline $.1 \cdots$ & $-11 / 49$ & $-\cdot / 4 q$ & $-\cdot|9|$ & \multirow{2}{*}{$19 r / \Delta \Lambda$} & \multirow{2}{*}{$(1-r \vee q)$} & \multirow{2}{*}{$\cdot / F \Delta$} & \multirow{2}{*}{$\cdot / 49$} & \multirow{2}{*}{$\cdot 19 \Lambda$} & انرزى حرفهاى \\
\hline$\cdot 1 \cdots$ & $9|9|$ & $\cdot / T \Lambda$ & $\cdot / \notin \Delta$ & & & & & & شيفتگى حرفهاى \\
\hline$\cdot 1 \cdot$ & $-\varepsilon / 49$ & $-\cdot / 11$ & $-\cdot / 1 f$ & \multirow{3}{*}{$I T V / T A$} & \multirow{3}{*}{$(1-r V \Lambda)$} & \multirow{3}{*}{.$/ 4 q$} & \multirow{3}{*}{$\cdot 10$} & \multirow{3}{*}{$\cdot / V$} & انرزى حرفهاى \\
\hline .1. & $1 / 9$. & $\cdot 10$. & $\cdot 1 \mathrm{~A}$. & & & & & & شيفتتى حرفهاى \\
\hline 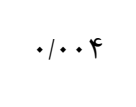 & $-\omega / 9 V$ & $-\cdot / r q$ & $-\cdot / r V$ & & & & & & نمرة كلى اشتياق \\
\hline
\end{tabular}

باورهاى خودكارآمدى فردى اين ضريب تبيين به • •ه| ·

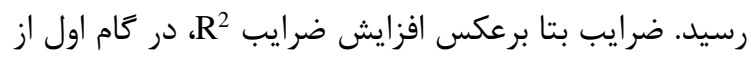

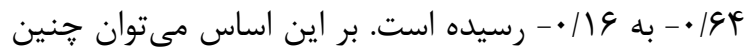
استنباط كرد كه بر مبناى ضرايب استاندارد رگرسيون (م)،

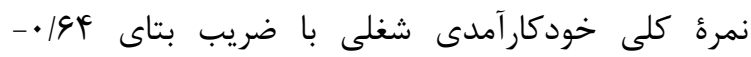
بيشترين سهمم را در ريشبينى تعارض -شغل خانواده دارد، و و

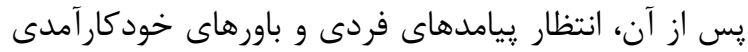

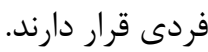

\section{بررسى فرضيةُ سوم يزوهش: بين خودكارآمدى} شغلى و تعارض شعل - خانواده يرستاران رابطه وجود دارد.

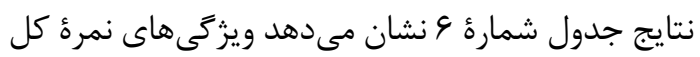
خودكارآمدى شغلى، انتظار زيامدهاى فردى و و باورهاى

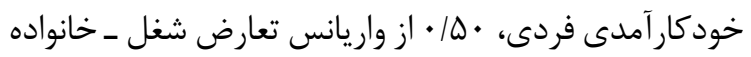

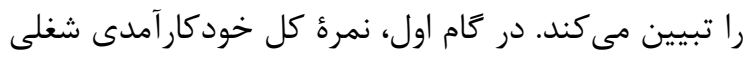
به تنهايى |f|٪ از واريانس تعارض-شغل خانواده را تبيين كرد و با اضافه شدن ويزگگىهاى انتظار ييامدهاى فردى و

جدول شماره צ. نتايج تحليل ركَرسيون كامبه كام براى پِيشبينى تعارض شغل ـ خانواده براساس خودكار آمدى شغلى

\begin{tabular}{|c|c|c|c|c|c|c|c|c|c|}
\hline معنى دارى & $\mathbf{T}$ & Beta & $\begin{array}{c}\boldsymbol{\beta} \\
\text { استاندارد }\end{array}$ & ل & df & تعديلشده & $\mathbf{R}^{2}$ & $\mathbf{R}$ & متغير هاى بيشبين \\
\hline
\end{tabular}

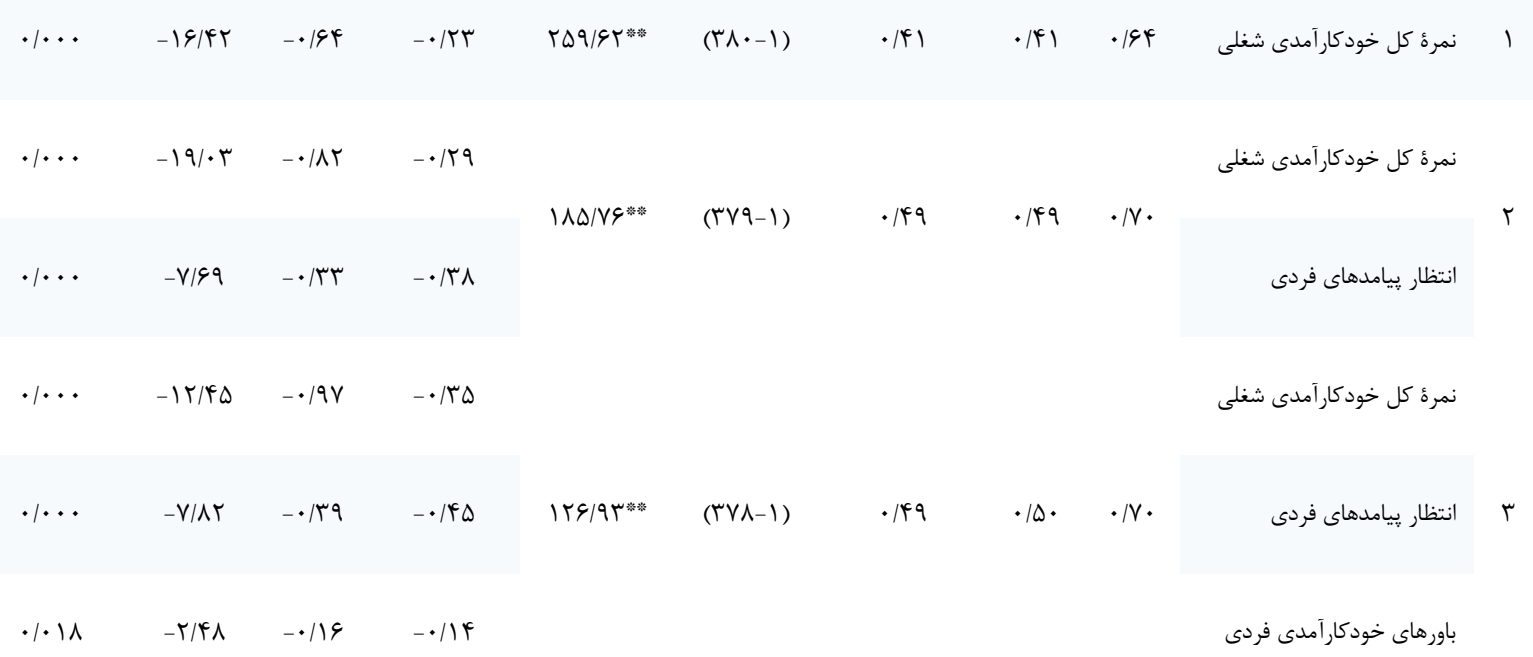


Bakhban يرستاران با تعارض كار - خانواده بالا و يايين، سطوح خودكار آمدى بالاو و يايينى نيز دارند.

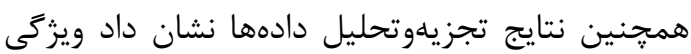
هاى انرزى حرفهاى، شيفتگى حرفهاى و نمرة كل اشتياق

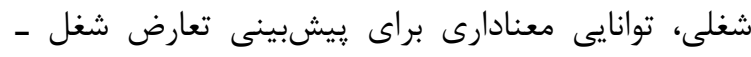

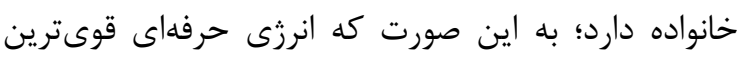
متغير پيشبينى كنندة تعارض كار- خانواده است. اين

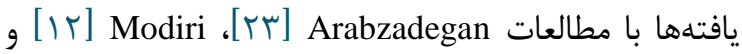
Nohe و همكاران [rF] هممسو است. اشتياق شغلى فرد در سازمانهايى مانند بيمارستان و بهويزه بين برستاران، مى الى

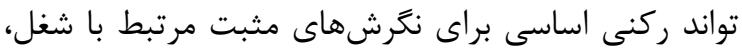

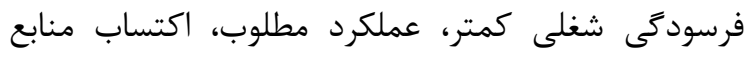
شغلى و فردى؛ بهويزه خودكار آمدى باشد. در نهائ نهايت همأ اين نتايج به شكل مستقيم يا غيرمستقيم به نفع خود سازمان

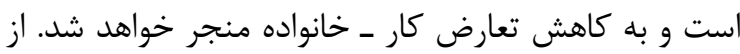
سوى ديكر انرزى حرفهاى، سطح بالايى از انرزى و انعطاف يذيرى ذهنى هنحام كار، تمايل (علاقه) به تلاش در كار و مقاومت در مقابل مشكلات كارى را ايجاد مى كند و مى نواند

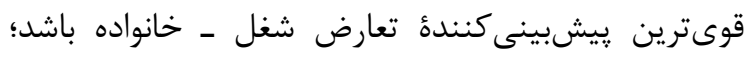

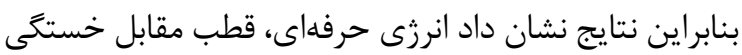

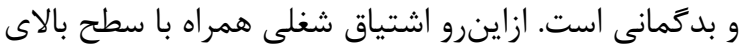

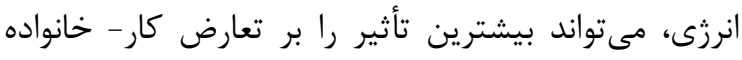

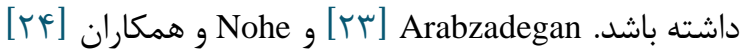
نيز به اين نتيجه رسيدند كه اشتياق شغلى توان بيشيشينى

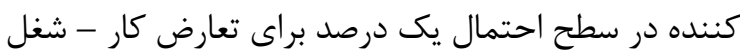
را دارد و با نتايج تحقيق حاضر همسو است. همجنين نتايج تجزيهوتحليل دادهها نشان داد ويزگى هاى نمرة كل خودكار آمدى شغلى، انتظار بِيامدهاى فردى و باورهاى خودكار آمدى فردى، توانايى معنادارى برى براى بـى بيش

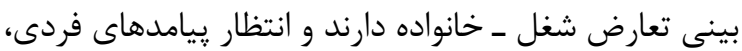
قوىترين متغير بيشبينى كننده تعارض كار - خانواده است.

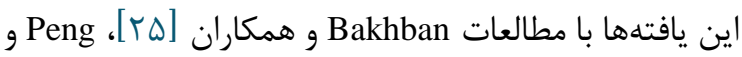

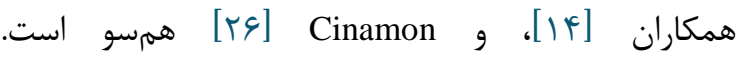

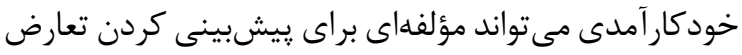
كار - خانواده باشد. همجنين انتظار ريامدهاى فردى ترين متغير بيشبينى كنندة تعارض كار - خانواده است؛ به به طورى كه تلاش براى دستيابى به آرزوهاى اجتماعى، ذهنى
نتايج يافتههاى يزوهش نشان داد بين نمرءٔ كل اشتياق

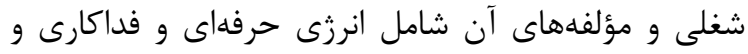

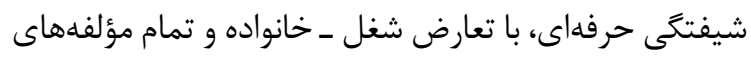
آن ارتباط منفى معنادارى وجود دارد. همجنين بارين بين مؤلفههاى خودكارآهدى شغلى و نمرة كل خودكارآمدى با مباديا تعارض شغل ـ خانواده و تمام مؤلفههاى آن ارتباط منفى ونى

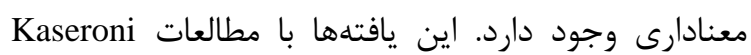

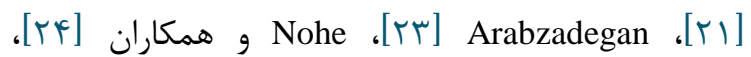
Rubio

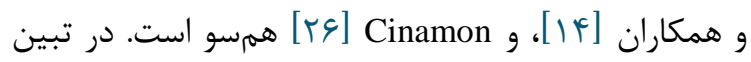
اين يافتهها مىتوان كفت تعارض كار - خانواده، جالشى براى يرستاران و حرفهٔ يرستارى محسوب مىشود، اما به به نظر مىرسد افرادى كه در حرفه و شغل خود اشتياق شغلى بردان بيشترى دارند، تعارض كار ـ خانوادة كمترى را تجربه خواهند

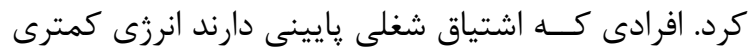

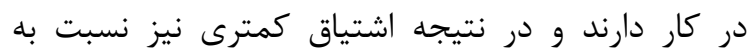

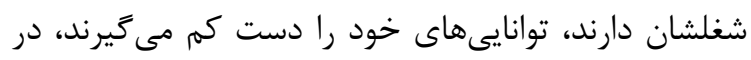

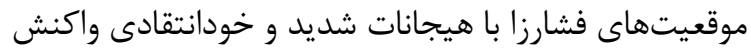

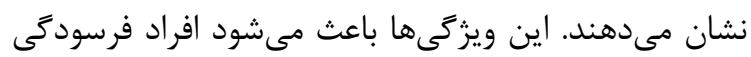

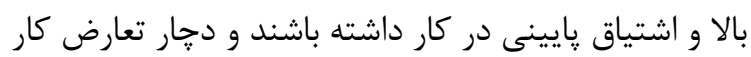

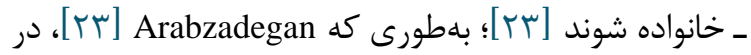
تحقيق خود بيان كرد اشتياق شغلى و مؤلفههاى آن، بران

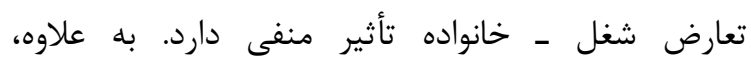
خودكارآمدى شغلى نكرانى فرد را نسبت به از دست دادئ دادن اردان

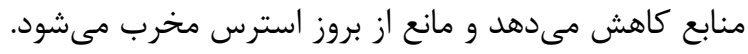

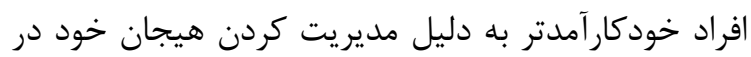
موقعيت تنشزا، سلامت جسمانى و روانى بالاترى دارند. از آنجا كه اين افراد از نظر ذهنى دركير منابع از دسترفت

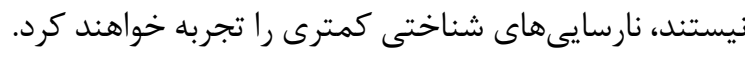

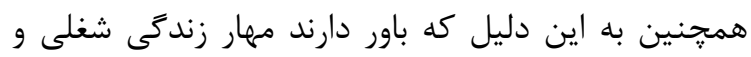

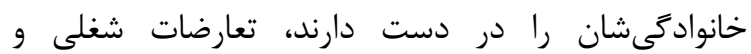

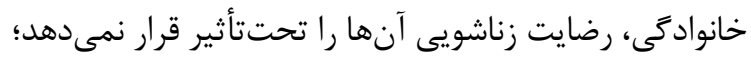

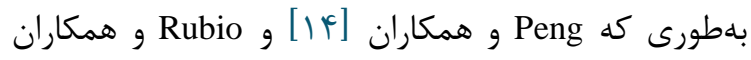

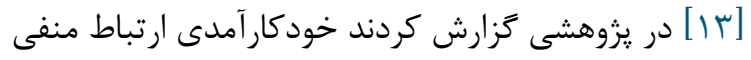

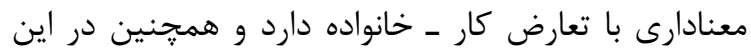

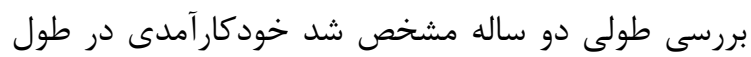

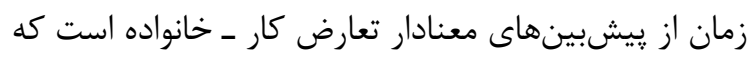
باعث كاهش تعارض كار- خانواده مىشود. همجنين 
براى شغل يرستارى كه از مشاغل سخت و حياتى محسوب

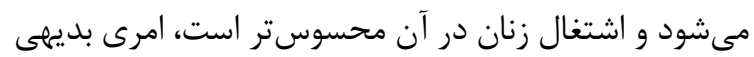
و واضح است؛ بنابراين براى كاهش تعارضات كار ــ خانواده، استفاده از راهبردهاى فردى و سازمانى، لازم و ضرورى به به نظر مىرسد. در نتيجه به مديران آموزشى بيمارستانها

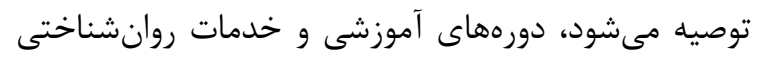

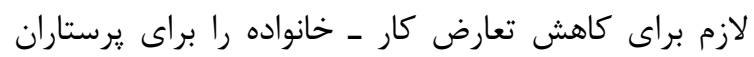
بلهويزه زنان شاغل و متأهل در دستور كار خود قرار دهند. محدوديت يزوهش: از محدوديتهاى يزوهش حاضر مى نى ند

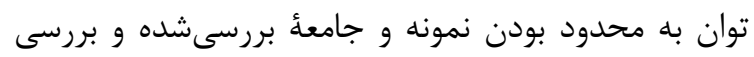
نشدن گروههاى سنى و جنسيتى (برستاران مرد) اشاره كرد.

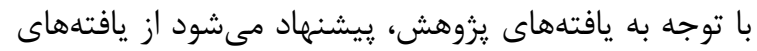

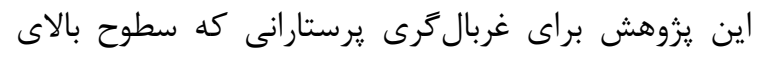

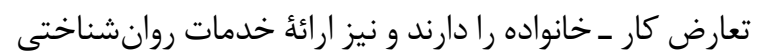

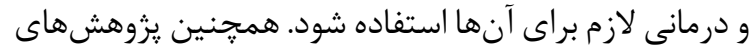

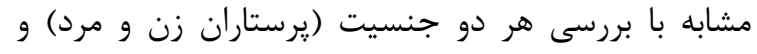
مقايسٔ نتايج براى افزايش تعميميذيرى نتايج انجام شود.

$$
\text { سياسخَزارى }
$$

يزوهش حاضر بركرفته از ياياننامٔ كارشناسىارشد

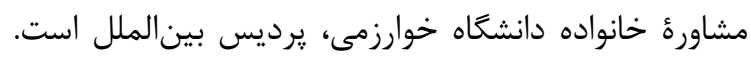

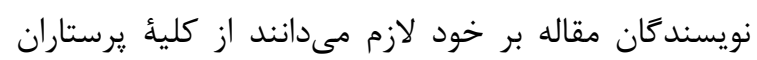
بيمارستانهاى همكارى كننده، تشكر و قدردانى كنند.

$$
\text { تعارض در منافع }
$$

بين نويسندكان هيجَّونه تعارضى در منافع وجود ندارد

\section{References}

1. Sveinsdottir H, P Biering, Ramel A. Occupational stress, job satisfaction, and working environment among Icelandic nurses: a cross-sectional questionnaire survey. Int J Nurs Stud. 2006; 43(7):875-89.

https://doi.org/10.1016/j.ijnurstu.2005.11.002

2. Grzywacz JG, Frone MR, Brewer CS, Kovner CT. Quantifying work-family conflict among registered nurses. Research in nursing \& health. 2006;29(5):414-26.

3. Tyson PD, Pongruengphant R. Five-year follow-up study of stress among nurses in public and private hospitals in Thailand. Int J Nurse Stud. 2004;
و فيزيكى، در كسانى كه انتظار ييامدهاى فردى در آنها زياد

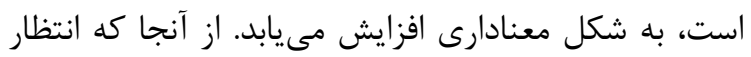

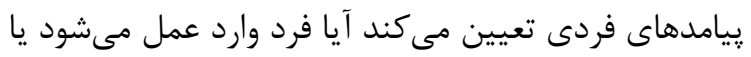

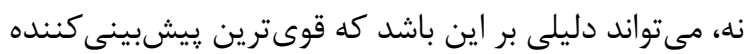

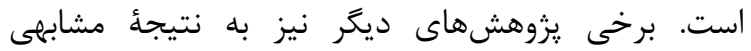

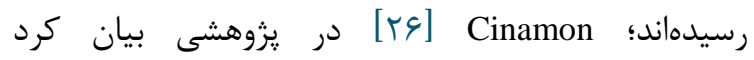
خودكار آمدى، علاوه بر ارتباط منفى با تعارض كار ـ خانواده،

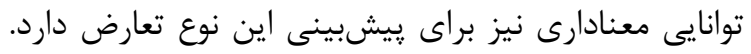

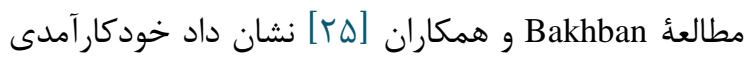

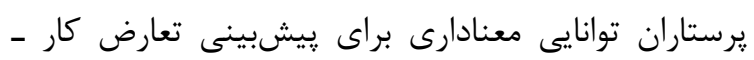

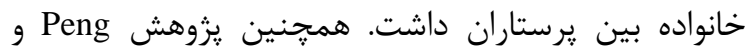

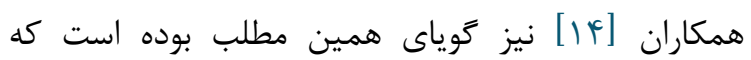
خودكار آمدى و رضايت شغلى، با تعارض كار ـ خانواده ارتباط

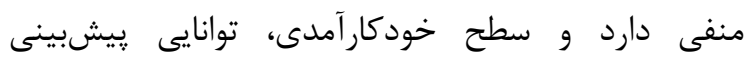
معنادارى در تعارض كار ـ خانواده دارد.

$$
\text { نتيجه كيرى }
$$

نتايج يروهش نشان داد بين نمرء كل اشتياق شغلى و

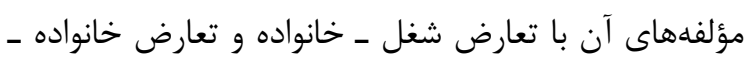
شغل ارتباط منفى معنادارى وجود دارد. همجنين بين آنارين

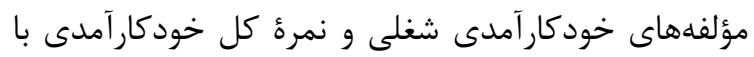

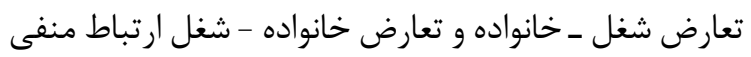

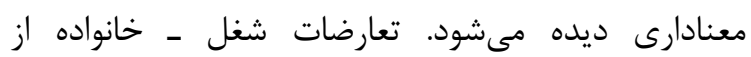

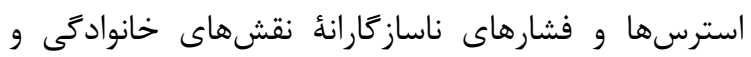

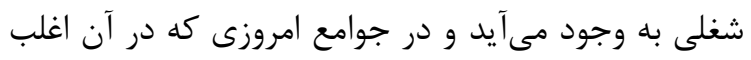
زوجها هر دو شاغلند، امرى اجتنابنايذير است. اين مسئله

41(3):247-54. $\quad$ https://doi.org/10.1016/S00207489(03)00134-2

4. Wayne SJ, Lemmon G, Wilson M. Work-Family Conflict and Career Outcomes: Differential Effects of Manager Supportive Behaviors. InAcademy of Management Proceedings 2013.2013(1): 16442. Briarcliff Manor, NY 10510: Academy of Management.

5. Keshavarz L, Bazazzadeh H, Jafari A. determination the predictive factors of job selfefficacy of managers of Sports Departments of Tehran Province, sport management studies.2014;6(12): 37-54.

6. Schaufeli WB, Martinez IM, Gonzalez-Roma V, Salanova M, Bakker AB. The measurement of engagement and burnout: A two sample confirmatory factor analytic approach. J Happiness 
Stud.2002 3:71-92. https://doi.org/10.1023/A:10156 $\underline{30930326}$

7. Rostami R, Shahmohamadi K, Ghaedi G, Besharat MA, Akbari Zardkhaneh S, Nosratabadi M. Relations among self-efficacy, emotional intelligence and perceived social support in university students. The Horizon of Medical Sciences. 2010 Dec 15;16(3):46-54.

8. Young ME, Long LL. Counseling and therapy for couples. Thomson Brooks/Cole Publishing Co; 1998.

9. Greenhaus JH, Beutell NJ. Sources of conflict between work and family roles. Academy of management review. 1985 Jan 1;10(1):7688.https://doi.org/10.5465/amr.1985.4277352

10. Clark MA, Early RJ, Baltes BB, Krenn D. WorkFamily Behavioral Role Conflict: Scale Development and Validation. Journal of Business and Psychology. 2018:1-5.

11. Aycan Z, Eskin M. Relative contributions of childcare, spousal support, and organizational support in reducing work-family conflict for men and women: The case of Turkey. Sex roles. 2005;53(7-8):453-71.

12. Lim S, Tai K. Family incivility and job performance: A moderated mediation model of psychological distress and core self-evaluation. Journal of Applied Psychology. 2014 Mar;99(2):351.

13. Rubio C, Osca A, Recio P, Urien B, Peiró JM. Work-family conflict, self-efficacy, and emotional exhaustion: A test of longitudinal effects. Revista de Psicología del Trabajo y de las Organizaciones. 2015;31(3):147-54.

https://doi.org/10.1016/j.rpto.2015.06.004

14. Wang P, Lawler JJ, Shi K. Work-Family Conflict, Self-Efficacy, Job Satisfaction, and Gender: Evidences From Asia. Journal of Leadership \& Organizational Studies. 2010 Aug;17(3):298-308.

https://doi.org/10.1177/1548051810368546

15. Krejcie RV, Morgan DW. Determining sample size for research activities. Educational and psychological measurement. 1970;30(3):60710.https://doi.org/10.1177/001316447003000308

16. Carlson D, Kacmar K \& Williams L. Construction and initial validation of a multidimensional measure of work-family conflict. J Vocat Behav.2000; https://doi.org/10.1006/jvbe.1999.1713

17. Watai I, Nishikido N, Murashima S. [Development of a Japanese Version of the Work-Family Conflict Scale (WFCS), and examination of its validity and reliability]. Sangyo Eiseigaku Zasshi. 2006;48(3):71-8 $\underline{\text { https://doi.org/10.1539 }}$ /sangyoeisei.48.71 PMID:16801732
18. Mauno S, Kinnunen U, Ruokolainen M. Job demands and resources as antecedents of work engagement: A longitudinal study. Journal of vocational behavior. 2007;70(1):149-71. https://doi.org/10.1016/j.jvb.2006.09.002

19. Hayati D, Charkhabi M, Naami A. The relationship between transformational leadership and work engagement in governmental hospitals nurses: a survey study. Springerplus. 2014;3:25. https://doi.org/10.1186/2193-1801-3-25 PMID:24455469

20. Chelariu C, Stump R. A study of work-family conflict, family-work conflict and the contingent effect of self-efficacy of retail salespeople in a transitional economy. European Journal of Marketing. 2011 Nov 15;45(11/12):1660-79. https://doi.org/10.1108/03090561111167333

21. Marashian FM, Naderi FA. Relations of Organizational Culture, Emotional Intelligence and Psychological Capital with Job Self-efficacy and Organizational Entrepreneurship among the Employees of Khuzestan Water and Power Organization. JSR. 2014;14(53):112-21.

22. Kaseroni F. Relationship between work-family conflict with general health, cognitive impairment in the workplace and marital satisfaction: Moderating role of sleep quality and self-efficacy of work-family conflict in employees of Aghajari oil and gas exploitation company. Master thesis of public psychology, Shahid Chamran University of Ahvaz.2013.

23. Arabzadegan M. the relationship between job engagement and job conflict with employees family and health regarding to the moderating role of supervisor support and family support in the employees of Isfahan Oil Refining Company. MS. in Social Sciences, Islamic Azad University, Isfahan Branch.2012

24. Karatepe OM, Karadas G. Service employees' fit, work-family conflict, and work engagement. Journal of Services Marketing. 2016;30(5):554-66. https://doi.org/10.1108/JSM-02-2015-0066

25. Bakhban K, Mackay H, Fateh Zadeh J. The relationship of organizational learning, general self-efficacy and career path with the enthusiasm of managers in Isfahan Steel Company. Master's Degree in Social Sciences, Islamic Azad University, Isfahan Branch. 2010

26. Cinamon RG. Anticipated work-family conflict: Effects of gender, self-efficacy, and family background. The Career Development Quarterly. 2006 Mar;54(3):202-15. 